\title{
Effect on Organoleptic Properties of Biscuits Fortified with Fenugreek Seed Germinated Until 5 Days
}

\author{
Huda A. Al- Gemeai ${ }^{1}$
}

\begin{abstract}
The objective of this study was to evaluate the effect of fortification of biscuits with $10 \%, 20 \%$ and $30 \%$ of fenugreek seed that germinated for $2,3,4$, and 5 days. The Organoleptic properties results showed that a maximum of $10 \%$ germinated fenugreek flour (GF) for 2 and 3 days can be incorporated to prepare acceptable quality biscuits. But 10 and $20 \%$ germinated fenugreek flour is preferred when increasing germination time for 4 and 5 days. Increased in the germination time and percent of adding germinated fenugreek flour to wheat flour altered the contents of protein and dietary fiber. These biscuits can be safely stored in polypropylene bags up to 2 month without altering their organoleptic properties.
\end{abstract}

Key words: fenugreek- Germination - Organoleptic properties

\section{INTRODUCTION}

Fenugreek (Trigonella foenum-gracum) is one of the most promising medicinal herbs, known from ancient times, having nutritional value too. They are used in India as a condiment and in Egypt as a supplement to wheat and maize flour for bread making; in Yemen, they are considered to be one of the essential dietary components of the general population (AL-Habori, et al. 2002; Meghwal and Goswami, 2012). Balbaa (2007) showed that two fenugreek cultivars cv. Giza-2 and cv. Giza-30 were significantly different in growth characters at the different stages of growth and yield and its components, as well as, chemical constituents of seeds (carbohydrates, proteins, and fixed oil percentages).

Germination is one of the methods used in elimination of various anti-nutritional factors present in foods. This is the process by which amylase degrade starches into dextrin and maltose. The enzymes convert the stored foods such as insoluble carbohydrates and proteins into soluble components (Mahmoud, et al., 2012).

The term cookies, or biscuits as they are called in many parts of the world, refers to a baked product generally containing the three major ingredients flour, sugar and fat. These are mixed together with other minor ingredients to form dough (Mamat, et al, 2010). Biscuits are convenient food products, becoming very popular among both rural and urban populations. Some of the reasons for such wide popularity are low cost among other processed foods, varied taste, easy availability and longer shelf life (Gandhi, et al., 2001).

The enrichment of protein may be achieved through incorporation of protein-rich non-wheat flours, among them fenugreek seed flour has a great potential, due to its high and good quality protein (20-25\%), lysine (5$6 \%$ ), soluble $(20 \%)$ and insoluble dietary fiber and, it also possesses hypocholesterolemic (Sharma and Chauhan, 2002). Therefore the aim of this study was to investigate the effect of fortification biscuits with germinated fenugreek seed until 5 days on Chemical and Organoleptic properties.

\section{MATERIALS AND METHODS}

Fenugreek seed was obtained from the Saudi's market, they were first cleaned and freed of broken seeds, dust and other foreign materials and then soaked in tap water for $12 \mathrm{~h}$ at $37^{\circ} \mathrm{c}$. A seed to water ratio of 1:5 (w/v) was used. The unimbibed water was discarded. The soaked seeds were germinated in sterile Petri- dishes lined with wet filter papers for 2, 3, 4, 5 days at $37^{\circ} \mathrm{c}$ with frequent watering. The sprouts were rinsed in distilled water and dried at $55-60^{\circ} \mathrm{c}$. The dried samples were ground to fine powder in an electric grinder and then stored in plastic containers for further use. Germinated fenugreek seed powder was blended separately with wheat flour at different levels namely, $10 \%, 20 \%$ and $30 \%$.

Preparation of biscuits: The sweet biscuits were prepared by using the AACC method (AACC, 1984) with slight modification. The ingredients included wheat flour or blends $100 \mathrm{~g}$, sugar $10 \mathrm{~g}$, fat $30 \mathrm{~g}$, common salt $2 \mathrm{~g}$, sodium bicarbonate $1.0 \mathrm{~g}$, ammonia $50 \mathrm{~g}$, vanilla $0.025 \mathrm{~g}$ and required amount of water. Preparation of biscuits was carried out using wheat flour samples replaced, separately, with $10 \%, 20 \%$ and $30 \%$ fenugreek seed that germinated for 2, 3, 4, and 5 days flour (GF2, GF3, GF4 and GF5, respectively). Shortening and creaming technique were used. The biscuits were baked at $160^{\circ} \mathrm{c}$ for $20 \mathrm{~min}$. After cooling for $30 \mathrm{~min}$, the cookies were packed and used for evaluation of various physical and sensory characteristics.

Chemical Composition: Fenugreek seeds (FS), germinated fenugreek (GF) and prepared biscuits (CB, FSB and GFB) were chemically analyzed for moisture, 
crude protein, fat, crude fiber and ash according to methods described in (AOAC, 2006). Total carbohydrates were calculated by difference. The energy value was calculated using the Atwater factors of 4,9 and 4 for protein, fat and carbohydrate, respectively (Chaney, 2006). Total soluble fiber was determined by following the enzymatic method (Furda, 1981). Natural detergent fiber (NDF), Acid detergent fiber (ADF), Acid detergent Lignin (ADL), hemicellulose, and cellulose were determined according to AOAC (2006) and Van Soest, et al.(1991). Total Minerals: Samples were wet acid-digested, using a nitric acid and perchloric acid mixture (HNO : $\mathrm{HClO}$, $5: 1 \mathrm{w} / \mathrm{v})$. The total amounts of $\mathrm{Ca}, \mathrm{Fe}, \mathrm{Mn}, \mathrm{Mg}$ and $\mathrm{Zn}$ in the digested samples were determined by atomic absorption spectrophotometry (Thermo-Elmental, Model 300VA, UK, 1969). Anti-nutritional Factors: Phytic acid was determined by the method of Hang and Lantzsch Hang (1983). Total polyphenols were extracted by the method of Singh and Jambunathan (1981) and estimated as tannic acid equivalents, according to the Folin-Denis procedure (Swain and Hills, 1959).

Sensory characteristics: The organoleptic characteristics of biscuits were determined, using a taste panel, consisting of 10 judges. The panelists were asked to evaluate the products for appearance, color, texture, flavour and overall acceptability. The ratings were on a 9-point hedonic scale, ranging from 9 (like extremely) to 1 (dislike extremely), for each organoleptic characteristic (Austin and Ram, 1971). Results were subjected to analysis of variance.

Statistical Analysis: Data were presented as means \pm standard deviation (SD). Values were statistically analyzed by one-way analysis of variance (ANOVA test) according to Sendecor and Cochran (1967) using SPSS 22 software package. Differences were considered significant at $\mathrm{P}$ values 0.05 using Duncan Multiple Range test.

\section{RESULTS AND DISCUSSION}

Data presented in Table (1) showed the chemical composition of raw and germinated fenugreek for 2, 3 , 4 and 5 days (GF2, GF3, GF4, and GF5). From the obtained data, it could be noticed that raw fenugreek contained (on dry weight basis) $26.76 \%$ crude protein, $8.55 \%$ fat, $5.12 \%$ ash, $8.25 \%$ crude fiber and 389.29 Kcal energy. These results were similar to the findings of Mahmoud, et al. (2012). The effect of germination on the chemical composition of fenugreek seeds showed significant increase $(p<0.05)$ of crude protein and crude fiber (on dry weight basis) especially on the fourth and fifth days of germination. These results agree with the earlier reports of increased protein content during germination of various cereals, legumes and other seeds (Inyang and Zakari , 2008, Yagoub, et al.,2008). Abd El-Aal and Rahma (1986) demonstrated that germination of fenugreek seeds for 3 and 5 days increased moisture, crude protein, crude fiber, nonprotein nitrogen and ash contents, but total lipids and carbohydrates were decreased. Marked increases of $\mathrm{Mg}$ and $\mathrm{Zn}$ were observed.

The chemical composition, antinutritional factors of Fenugreek seeds (raw and germinated) from two different origins (Saudi and Yemeni cultivars) were determined. Raw fenugreek seeds of the two cultivars contained high amount of dietary nutrients especially protein. Germination significantly increased the total protein and fiber, decreased the dry matter and carbohydrates, while ash and oil remained unchanged (Alhussain, 2010). Such increase could be attributed to a net synthesis of enzymic protein (e.g. proteases) by germinating seeds (Nzeribe and Nwasike,1995). Other researchers have attributed the increase to the degradation of stored protein and synthesis of new protein.

There were high significant differences $(\mathrm{P}<0.05)$ in carbohydrate and total lipid content between germinated and fenugreek seed on dry weight basis. The percent of fat were 8.55 and 5.99 of seed and germinated fenugreek for five days respectively (Table 1). The observed decrease in the fat content of the germinated seeds might be due to the increased activities of the lipolytic enzymes during germination. The decreased carbohydrate levels of the germinated seeds might be due to increase in $\alpha$-amylase activity, which breaks down complex carbohydrates to simpler and more absorbable sugars which are utilized by the growing seedlings during the early stages of germination (Elegbede, 1998, Inyang and Zakari , 2008). Natural detergent fiber (NDF) and Hemicellulose were significantly increased $(p<0.05)$ as increased the time of germination. Meghwal and Goswami (2012) reported that $100 \mathrm{~g}$ of fenugreek seeds provide more than $65 \%$ of dietary fiber due to its high fiber content and it has an ability to change food texture. Germinated seeds on the fifth day had the significantly highest iron and zinc content 307.75 and $82.05 \mathrm{mg} / 100 \mathrm{~g}$ respectively. The increase might be due to the hydrolytic enzymes released more free $\mathrm{Fe}$ from its organic complexes. These results were similar with those reported by Echendu, et al. (2009). But the highest calcium content $196.03 \mathrm{mg} 100 \mathrm{~g}$ were on the fourth day of germination.

Data presented in Table (1) illustrate the polyphenol and phytic acid contents of raw and fenugreek germinated for 2,3,4,5 days. It is obvious that, there were significant decrease $(\mathrm{P}<0.05)$ in polyphenol contents and phytic acid as increased the time of 
germination. Raw fenugreek seed had higher polyphenol and phytic acid contents $288.53,312.11$ $\mathrm{mg} / 100 \mathrm{~g}$ respectively as a compared with germinated seeds for 2 ,

3, 4, 5 days $(269.00,209.75$ and $239.00,198.50$ and $218.14,169.20$ and $199.40,124.16$ respectively). The higher phytic acid contents for the ungerminated seeds might not be due to the tannin activity during germination. Dxiti, et al. (2005) revealed significant antioxidant activity in germinated fenugreek seeds which may be due partly to the presence of flavonoids and polyphenols

The effects of fenugreek supplementation on the sensory characteristics of biscuits are presented in Table 2. With the increase in the level of fenugreek seed flour in formulation, the sensory scores for color, taste, odor, texture and appearance of biscuits decreased sharply. Replacement of flour with $20 \%$ and $30 \%$ fenugreek seed flour decreased the overall acceptability of biscuits. The overall acceptability score for control was 7.08 on a 9-point hedonic scale which decreased significantly from 6.10 to 3.85 respectively, which might be due to the bitter taste of fenugreek. The control samples had maximum overall acceptability, whereas biscuits containing 20\% and 30\% germinated fenugreek flours for two and three days were found to be unacceptable to the panelists. Biscuits made from blends containing $10 \%$ level of all germinated fenugreek flours did not differ significantly $(\mathrm{P}<0: 05)$ from the control. These results were in agreement with Hooda and Jood (2005), they showed that a maximum of $10 \%$ of raw or germinated fenugreek flour can be incorporated to prepare acceptable quality biscuits.

Biscuits made from blends containing 10 and $20 \%$ level of germinated fenugreek flours are preferred when increasing germination time up to 4 and 5 days as a compered with control group, especially taste, odor and texture of biscuits prepared from fenugreek germinated for 4 days, and color, odor and appearance of biscuits prepared from fenugreek germinated for 5 days. Hooda and Jood (2005) reported that germinated fenugreek flour- supplemented biscuits performed better than raw or soaked fenugreek-supplemented biscuits. From the overall acceptability rating, it was concluded that increasing the time of fenugreek germination up to 5 days could be incorporated up to $20 \%$ level in the formulation of biscuits without affecting their sensory quality.

Table 3 shows that the crude protein, ash and crude fiber of biscuits contents increased with increasing fenugreek (raw and germinated) flour in wheat flour and also with increasing the time of germination, whereas total carbohydrate contents decreased from $67.0 \%$ (control biscuits) to $50.16 \%$ (germinated fenugreek for 5 days). Control biscuits had $9.62 \%$ protein content. In the case of supplemented biscuits, the highest percent of crude protein $20.24 \%$ for germinated fenugreek for 5 days. The increase in protein content of fenugreek supplemented biscuits might be the result of the appreciably higher protein content of fenugreek. Mahmoud, et al. (2012) also reported that Wheat flour supplemented by 5 and $10 \%$ germinated fenugreek produced high nutritive values of biscuits, crude protein, fat and crude fiber increased by increasing the GF level, whereas total carbohydrate contents decreased in biscuits fortified with GF. The decreased carbohydrate levels of the germinated seeds might be due to increase in $\alpha$-amylase activity, which breaks down complex carbohydrates to simpler and more absorbable sugars which are utilized by the growing seedlings during the early stages of germination (Inyang and Zakari, 2008).

\section{Mineral composition}

Mineral composition in the control as well as supplemented biscuits are presented in Table 4. Control biscuits had low total iron $(5.12 \mathrm{mg} / 100 \mathrm{~g}), \mathrm{Mn}(0.22$ $\mathrm{mg} / 100 \mathrm{~g}), \mathrm{Mg}$ (20.22 mg/100 g), Ca (58.20 mg100g) and $\mathrm{Zn}(2.22 \mathrm{mg} 100 \mathrm{~g})$ contents. Mineral contents increased on increasing the substitution of raw and germinated fenugreek flour in wheat flour, and also on increasing the time of germination. This might be attributed to higher mineral contents of germinated fenugreek flour. As phytate hydrolyzed upon germination, the major phosphorus-bearing compounds in cereals, chelate divalent and trivalent cations, such as $\mathrm{Ca}, \mathrm{Fe}$ and $\mathrm{Zn}$, form insoluble complexes and thereby reduce the in vitro availability of minerals (Haug and Lantzsch, 1983).

The present results are in conformation with the findings of Kasaye and Jha (2015) that showed the nutritive values in terms of calcium, magnesium, iron and zinc content of biscuit increased as a result of the supplementation of germinated fenugreek flour to wheat flour at 5, 10, and 15\% levels.

\section{Sensory evaluation of stored biscuits}

Overall acceptability of the control and supplemented biscuits did not di er significantly ( $\mathrm{P}$ $<0: 05)$ up to 60 days of storage (Table 5). Control biscuits had 7.08, 7.08, 7.08, and 7.00 overall acceptability scores at $0,15,30,45$ and 60 days of storage. Among supplemented biscuits, germinated fenugreek for 2, 3, 4, 5 days, at 10\% level, had higher overall acceptability scores $(5.28,5.28,5.20,5.00$ and $4.88),(5.46,5.46,5.40,5.22$, and 5.00), (5.51, 5.50, $5.44,5.00$ and 4.90$)$ and $(5.91,5.91,5.89,5.82$ and $5.79)$ at $0,15,30,45$ and 30 days of storage, 


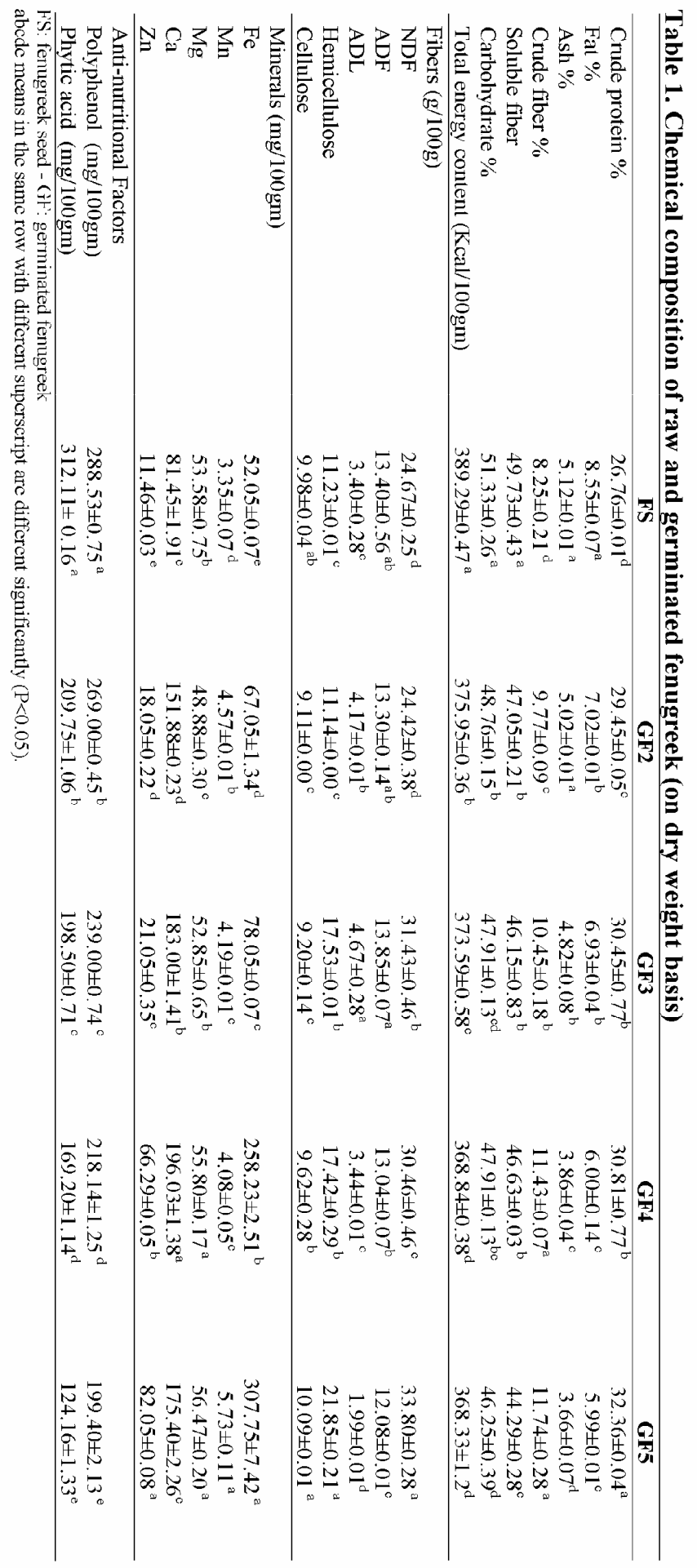




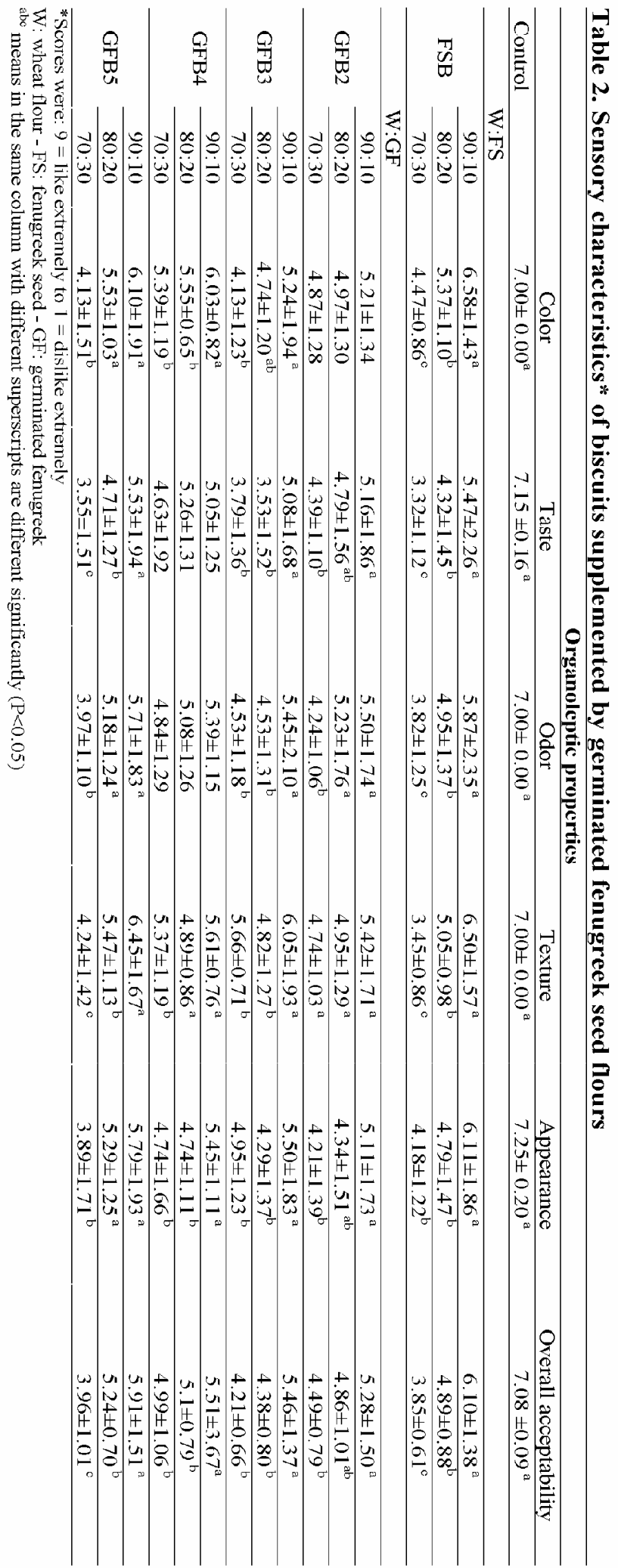




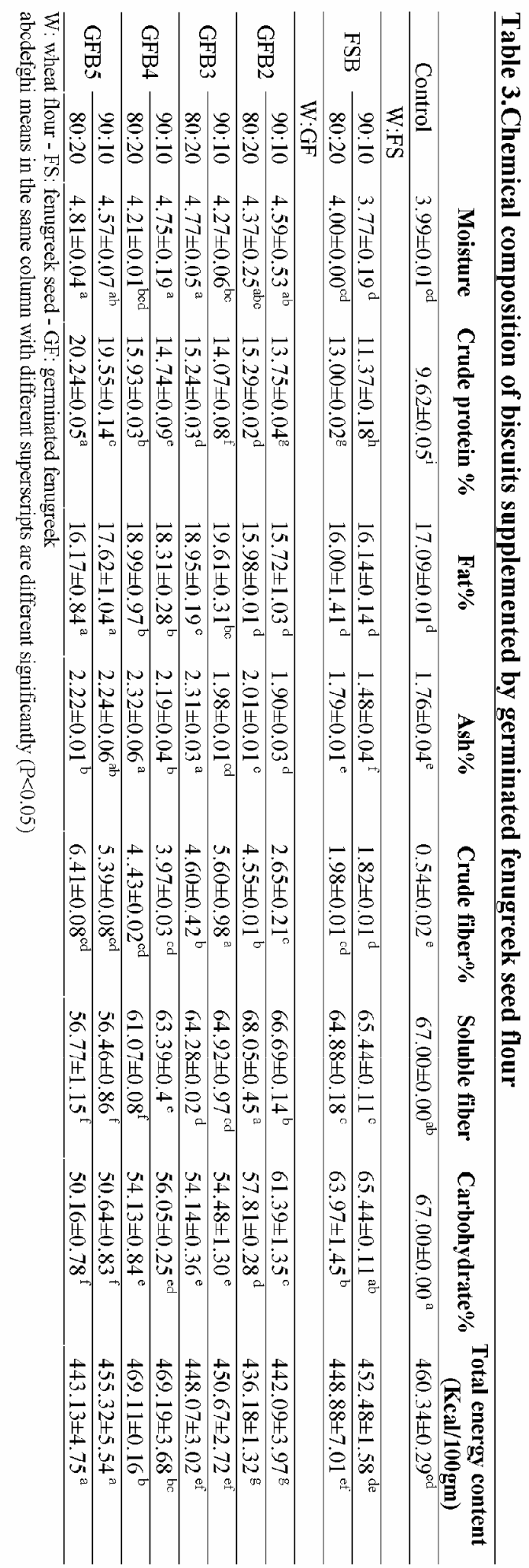


respectively. In addition to, supplemented biscuits, germinated fenugreek for 4 and 5 days, at level 20\%, had higher overall acceptability scores. It is therefore, concluded that overall acceptability scores of supplemented biscuits were still in the category of 'like moderately' up to 60 days of storage. Hence, supplemented biscuits can be stored safely in polyethylene bags at room temperature for 60 days without any adverse changes in the organoleptic traits.

In conclusion, Composite blends of germinated fenugreek seed flour for 2,3,4,5 days supplemented with wheat flour exhibited desirable nutritional properties. The crude protein and fiber as well as $\mathrm{Fe}, \mathrm{Mn}, \mathrm{Mg}, \mathrm{Ca}$ and $\mathrm{Zn}$ content of biscuits increased as a result of the addition of germinated fenugreek flour. The Organoleptic properties results showed that a maximum of $10 \%$ germinated fenugreek flour (GF) for 2 and 3 days can be incorporated to prepare acceptable quality biscuits. But 10 and 20\% germinated fenugreek flour is preferred when increasing germination time for 4 and 5 days. Increased in the germination time and percent of adding germinated fenugreek flour to wheat flour altered the contents of protein and dietary fiber. These biscuits can be safely stored in polypropylene bags up to 2 month without altering their organoleptic properties.

Table 4. Mineral composition (mg/100gm) of biscuits supplemented by germinated fenugreek seed flour

\begin{tabular}{|c|c|c|c|c|c|c|}
\hline & & $\mathbf{F e}$ & Mn & Mg & $\mathbf{C a}$ & Zn \\
\hline \multicolumn{2}{|c|}{ Control } & $5.12 \pm 0.13^{\mathrm{f}}$ & $0.22 \pm 0.02^{\mathrm{c}}$ & $20.22 \pm 0.80^{\mathrm{f}}$ & $57.20 \pm 0.34^{\mathrm{d}}$ & $2.22 \pm 0.00^{\mathrm{f}}$ \\
\hline \multicolumn{7}{|c|}{ W:FS } \\
\hline \multirow{2}{*}{ FSB } & $90: 10$ & $7.12 \pm 0.06^{\mathrm{e}}$ & $0.41 \pm 0.02^{\mathrm{a}}$ & $22.18 \pm 0.31^{\mathrm{e}}$ & $57.52 \pm 0.22^{d}$ & $2.31 \pm 0.07^{\mathrm{f}}$ \\
\hline & $80: 20$ & $7.65 \pm 0.10^{\mathrm{e}}$ & $0.47 \pm 0.01^{\mathrm{a}}$ & $27.00 \pm 0.21^{\mathrm{d}}$ & $57.10 \pm 0.45^{d}$ & $2.69 \pm 0.05^{\mathrm{e}}$ \\
\hline \multicolumn{7}{|c|}{$\mathrm{W}: \mathrm{GF}$} \\
\hline \multirow{2}{*}{ GFB2 } & $90: 10$ & $7.52 \pm 0.12^{\mathrm{e}}$ & $0.29 \pm 0.02^{b}$ & $24.31 \pm 0.06^{\mathrm{c}}$ & $57.22 \pm 0.16^{\mathrm{d}}$ & $2.91 \pm 0.10^{d}$ \\
\hline & $80: 20$ & $7.89 \pm 0.03^{d}$ & $0.33 \pm 0.04^{b}$ & $28.61 \pm 0.28^{d}$ & $59.10 \pm 0.14^{\mathrm{c}}$ & $3.17 \pm 0.20^{\mathrm{cd}}$ \\
\hline \multirow{2}{*}{ GFB3 } & 90:10 & $7.99 \pm 0.04^{\mathrm{d}}$ & $0.34 \pm 0.00^{b}$ & $26.31 \pm 0.11^{\mathrm{c}}$ & $59.77 \pm 0.78^{c}$ & $3.00 \pm 0.32$ \\
\hline & $80: 20$ & $8.50 \pm 0.10^{d}$ & $0.39 \pm 0.03^{\mathrm{ab}}$ & $30.21 \pm 0.60^{\mathrm{c}}$ & $62.45 \pm 0.66^{\mathrm{b}}$ & $4.10 \pm 0.88^{c}$ \\
\hline \multirow{2}{*}{ GFB4 } & $90: 10$ & $10.10 \pm 0.22^{\mathrm{c}}$ & $0.35 \pm 0.07^{b}$ & $33.41 \pm 0.68^{b}$ & $60.00 \pm 0.14^{\mathrm{c}}$ & $4.89 \pm 0.05^{\mathrm{c}}$ \\
\hline & $80: 20$ & $10.80 \pm 0.41^{\mathrm{c}}$ & $0.38 \pm 0.10^{\mathrm{a}}$ & $35.65 \pm 0.91^{\mathrm{b}}$ & $66.21 \pm 0.0^{\mathrm{a}}$ & $6.56 \pm 0.19^{b}$ \\
\hline \multirow{2}{*}{ GFB5 } & $90: 10$ & $11.25 \pm 0.06^{\mathrm{b}}$ & $0.44 \pm 0.41^{\mathrm{a}}$ & $36.45 \pm 0.01^{\mathrm{b}}$ & $62.12 \pm 0.16^{\mathrm{b}}$ & $6.12 \pm 0.07^{b}$ \\
\hline & $80: 20$ & $13.59 \pm 0.65^{\mathrm{a}}$ & $0.49 \pm 0.18^{\mathrm{a}}$ & $38.21 \pm 0.02^{\mathrm{a}}$ & $67.00 \pm 0.07^{\mathrm{a}}$ & $7.00 \pm 0.39^{\mathrm{a}}$ \\
\hline
\end{tabular}

W: wheat flour - FS: fenugreek seed - GF: germinated fenugreek

abcdef means in the same column with different superscripts are different significantly $(\mathrm{P}<0.05)$

Table 5. Effect of storage on overall acceptability of fenugreek supplemented biscuits

\begin{tabular}{|c|c|c|c|c|c|c|}
\hline \multicolumn{7}{|c|}{ Storage period (days) } \\
\hline & & $\mathbf{0}$ & 15 & 30 & 45 & 60 \\
\hline \multicolumn{2}{|l|}{ Control } & $7.08 \pm 0.09^{\mathrm{a}}$ & $7.08 \pm 0.10$ & $7.08 \pm 0.14$ & $7.08 \pm 0.12$ & $7.00 \pm 0.13$ \\
\hline \multicolumn{7}{|c|}{$\mathrm{W}: \mathrm{FS}$} \\
\hline \multirow{2}{*}{ FSB } & $90: 10$ & $6.10 \pm 1.38$ & $6.10 \pm 0.98$ & $6.00 \pm 1.23$ & $6.00 \pm 2.00$ & $5.89 \pm 0.66$ \\
\hline & $80: 20$ & $4.89 \pm 0.88$ & $4.88 \pm 1.08$ & $4.68 \pm 0.98$ & $4.40 \pm 1.88$ & $4.00 \pm 1.22$ \\
\hline \multicolumn{7}{|c|}{$\mathrm{W}: \mathrm{GF}$} \\
\hline \multirow{2}{*}{ GFB2 } & $90: 10$ & $5.28 \pm 1.50$ & $5.28 \pm 0.87$ & $5.20 \pm 1.05$ & $5.00 \pm 0.15$ & $4.88 \pm 0.12$ \\
\hline & $80: 20$ & $4.86 \pm 1.01$ & $4.80 \pm 1.01$ & $4.76 \pm 2.00$ & $4.70 \pm 1.00$ & $4.10 \pm 1.03$ \\
\hline \multirow[b]{2}{*}{ GFB3 } & $90: 10$ & $5.46 \pm 1.37$ & $5.46 \pm 1.37$ & $5.40 \pm 0.48$ & $5.22 \pm 1.12$ & $5.00 \pm 0.78$ \\
\hline & $80: 20$ & $4.38 \pm 0.80$ & $4.38 \pm 1.00$ & $4.28 \pm 0.00$ & $4.25 \pm 0.09$ & $4.10 \pm 0.078$ \\
\hline \multirow[t]{2}{*}{ GFB4 } & $90: 10$ & $5.51 \pm 3.67$ & $5.50 \pm 1.66$ & $5.44 \pm 0.90$ & $5.00 \pm 1.32$ & $4.90 \pm 0.09$ \\
\hline & $80: 20$ & $5.1 \pm 0.79$ & $5.1 \pm 1.21$ & $5.0 \pm 1.45$ & $4.99 \pm 0.09$ & $4.90 \pm 0.77$ \\
\hline \multirow{2}{*}{ GFB5 } & $90: 10$ & $5.91 \pm 1.51$ & $5.91 \pm 2.01$ & $5.89 \pm 1.11$ & $5.82 \pm 0.58$ & $5.79 \pm 0.01$ \\
\hline & $80: 20$ & $5.24 \pm 0.70$ & $5.24 \pm 1.00$ & $5.20 \pm 0.68$ & $5.00 \pm 1.45$ & $4.87 \pm 0.17$ \\
\hline
\end{tabular}

*Scores were: $9=$ like extremely to $1=$ dislike extremely

$\mathrm{W}$ : wheat flour - FS: fenugreek seed - GF: germinated fenugreek

Overall acceptability Non significant $(\mathrm{p}<0.05)$ for all Storage period 


\section{REFERENCES}

AACC. 1984. Approved methods of analysis. St. Paul, Minnesota: The American Association of Cereal Chemists.

Abd El-Aal M. and E. Rahma. 1986. Changes in gross chemical composition with emphasis on lipid and protein fractions during germination of fenugreek seeds. Food Chemistry. 22(3):193-207.

AL-Habori M. and A. Raman. Pharmacological properties of Trigonella foenum graecum. In: Petropoulos GA, editor. Medicinal and aromatic plants industrial profiles. London 7 Taylor \& Francis; 2002. p. 162-82.

Alhussain A. 2010. Effect of soaking and germination of fenugreek, trigonella foenum L. Seeds: changes in upon chemical and amino acid composition, antinutrients, protein digestibility and minerals extractability. Bulletin Cairo Unversity.61 (3):263-273.

AOAC 2006. Official Methods of Analysis of AOAC International (2000). $20^{\text {th }}$ ed. AOAC International, Arlington, VA, USA.

Austin A. and A. Ram 1971. Studies on chapati making quality of wheat, Indian Council of Agricultural Research, New Delhi. Technical Bulletin, 31. 96-101.

Balbaa L. 2007. Response of Two Fenugreek (Trigonella foenumgraecum L.) Cultivars to Foliar Application with Brassinosteroids. Alexandria Science Exchange Journal. 28(4):209-215.

Chaney S. 2006. Principles of Nutrition I: Macronutrients. In: Devlin, T.M. (ed.), Textbook of Biochemistry, with Clinical Correlation, 6th ed. John Wiley and sons, New York, pp: 1071-1090.

Dxiti P., S. Ghaskadbi, H. Mohan and T. Devasagayam. 2005. Antioxidant properties of germinated fenugreek seeds. Phytother Res. 19 (11): 977-983.

Echendu C., L. Obizoba and J. Anyika. 2009. Effects of germination on chemical composition of ground bean Kerstingiella geocarpa harm) seeds Pakistan Journal of Nutrition. 8: 1849-1854.

Elegbede J. 1998. Nutritional Quality of Plant Foods. PostHarvest Research Unit, Department of Biochemistry, University of Benin, Benin City. Nigeria. pp: 120-133.

Furda I. 1981. Simultaneous analysis of soluble and insoluble dietary fibre. In W. P. T. James \& O. Theander (Eds.), The analysis of dietary fibre in food (pp. 163-172). New York: Marcel Dekker.

Gandhi A., N. Kotwaliwale, J. Kawalkar, D. Srivastava, V. Parihar and P. Raghu Nadh. 2001. E ect of incorporation of defatted soy flour on the quality of sweet biscuits. Journal of Food Science and Technology, 38: 502-503.

Hang W. and H. Lantzch. 1983. Sensitive method for rapid determination of phytate in cereals and cereal products. J. Sci. Food. Agric. 34: 1423-1426.
Hooda S. and S. Jood 2005. Organoleptic and nutritional evaluation of wheat biscuits supplemented with untreated and treated fenugreek flour. Food Chemistry 90: 427-435.

Inyang C. and U. Zakari. 2008. Effect of Germination and Fermentation of Pearl Millet on Proximate, Chemical and Sensory Properties of Instant "Fura"- A Nigerian Cereal Food. Pak J. Nutr. 7: 9-12.

Kasaye A. and Y. Jha. 2015. Evaluation of composite blends of fermented fenugreek and wheat flour to assess its suitability for bread and biscuit. International Journal of Nutrition and Food Sciences. 4(1): 29-35

Mahmoud N., R. Salem and A. Mater. 2012. Nutritional and Biological Assessment of Wheat Biscuits Supplemented by Fenugreek Plant to Improve Diet of Anemic Rats. Academic Journal of Nutrition. 1 (1): 1-9.

Mamat H., M. Abu-Hardan and S. Hill. 2010. Physicochemical properties of commercial semi-sweet biscuit. Food Chemistry. 121(4): 1029-1038.

Meghwal M. and T. Goswami. 2012. A Review on the Functional Properties, Nutritional Content, Medicinal Utilization and Potential Application of Fenugreek. J Food Process Technol. 3(9): 1-11.

Nzeribe H. and C. Nwasike. 1995. The brewing potential of acha Digiteria exlils) malt compared with pearl millet Pennisetum glaucum) malt and sorghum Sorghum bicolar) malts. J. Inst. Brewing. 101:345-350.

Sendecor G. and W. Cochran. 1967. Statistical Methods. The Lowa State Univ. Press, Ames, U.S.A. $6^{\text {th }}$ ed.

Sharma H. and G. Chauhan. 2000. Physicochemical and rheological quality characteristics of fenugreek (Trigonella foenum L.) Seed. Pak. J. Nutr. 7: 50-56.

Sharma H. and G. Chauhan. 2002. E ects of stabilized rice bran-fenugreek blends on the quality of breads and cookies. Journal of Food Science and Technology, 39: 225 -233 .

Singh V. and R. Jambunathan. 1981. Studies on desi and kabuli chickpea cultivars. The level of protease inhibiters, level of phenolic compounds and invitro digestibility. J. Food Sc. 46: 1364.

Swain J. and W. Hills. 1959. The phenolic constituents of Pramus domesiicai: The qualitative analysis of phenolic constituents. Journal of Science and Food Agriculture. 10: 63-68.

Van Soest P., J. Robertson and B. Lewis. 1991. Methods for dietary fibre, neutral detergent fibre and nonstarch polysaccharides in relation to animal nutrition. J. Dairy Sci. 74: $3583-3597$.

Yagoub A., M. Mohammed and A. Baker. 2008. Effect of Soaking, Sprouting and Cooking on Chemical Composition, Bioavailability of Minerals and in vitro Protein Digestibility of Roselle (Hibiscus sabdariffa graecum L.) supplemented wheat flour. Journal of Food Science and Technology. 37: 87-90. 
Huda A. Al- Gemeai: Effect on Organoleptic Properties of Biscuits Fortified with Fenugreek Seed ...

205

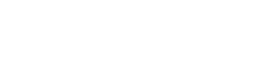

الخصائص المضوية الهسية اللبكويت المدعم ببنور الحلبة المنبتة حقى 0 ليلم هلدى بنت عبد الرحمن عويض الجميعي الميل

الإنبات لمة ع، 0 أيلم. تغير محتوي البروتين والأليف

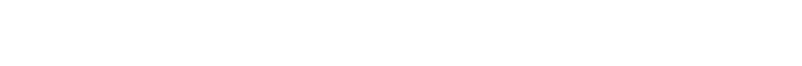

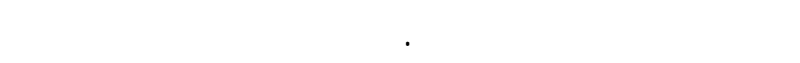

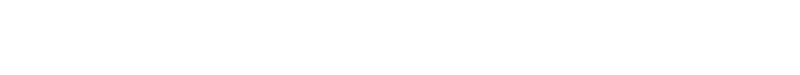
في أكيلس البولي بروبلين لمدة وصلت إلىشهرين.
لمستهفت هنه الدرلسة قييم تأثير تدعيم البسكويت بنسبة

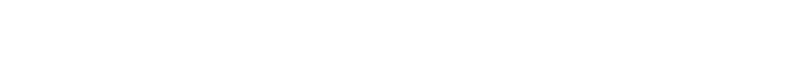

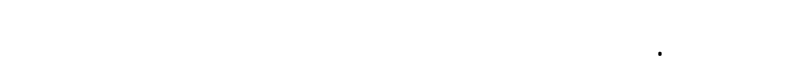

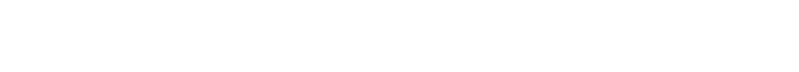

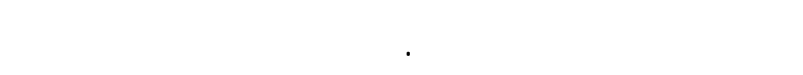

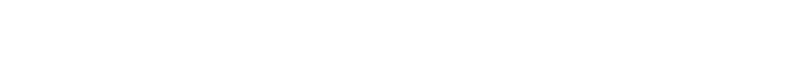

